IRA-International Journal of Technology \& Engineering

ISSN 2455-4480; Vol.05, Issue 03 (2016)

Pg. no. 56-69

Institute of Research Advances

http://research-advances.org/index.php/IRAJTE

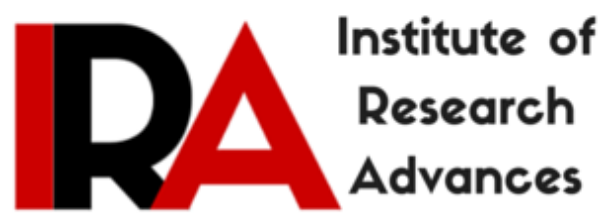

\title{
Assessment of Beach sand using Gamma Ray Spectrometer in Thiruvanathapuram District, Kerala of South India
}

\author{
Ajithra. A. $\mathbf{K}^{1}$, Shanthi. $\mathbf{G}^{2}$ \\ 1,2 Department of Physics \& Research Centre, \\ Women's Christian College, Nagercoil, India.
}

Type of Reviewed: Peer Reviewed.

DOI: http://dx.doi.org/10.21013/jte.v5.n3.p2

\section{How to cite this paper:}

Ajithra, A., \& Shanthi , G. (2016). Assessment of Beach sand using Gamma Ray Spectrometer in Thiruvanathapuram District, Kerala of South India. IRA-International Journal of Technology \& Engineering (ISSN 2455-4480), 5(3), 56-69. doi:http://dx.doi.org/10.21013/jte.v5.n3.p2

(C) Institute of Research Advances

(cc) $\mathrm{Br}-\mathrm{NC}$

This work is licensed under a Creative Commons Attribution-Non Commercial 4.0 International License subject to proper citation to the publication source of the work.

Disclaimer: The scholarly papers as reviewed and published by the Institute of Research Advances (IRA) are the views and opinions of their respective authors and are not the views or opinions of the IRA. The IRA disclaims of any harm or loss caused due to the published content to any party. 


\section{ABSTRACT}

It is well recognized fact that some areas of the world have anomalously high levels of natural background radiation referred to as high background radiation areas (HBRAs). Typical examples include Yangjiang in China, Rasmar in Iran and In India, part of coastal areas of Kerala and Tamil Nadu fall in this category. It has been established earlier that the cause for this high background is the presence of monazite (thorium). This study focuses on the estimation of the environmental radioactivity levels in the beach sands of Thiruvanathapuram district, Kerala.

Using high resolution gamma ray spectroscopy activity concentrations of ${ }^{40} K,{ }^{238} U$ \& ${ }^{232}$ Th were estimated. Activity concentrations ranged from $17-154 \mathrm{~Bq} / \mathrm{kg}$ for ${ }^{40} \mathrm{~K}$, from 4 to $100 \mathrm{~Bq} / \mathrm{kg}$ for ${ }^{238} \mathrm{U}$ and from 6 to $296 \mathrm{~Bq} / \mathrm{kg}$ for ${ }^{232}$ Th. The mean activity concentration values obtained for the radionuclide are below than the world average values reported by the UNSCEAR. Subsequently assessed radiological effects show that the mean radium equivalent activity is $65 \mathrm{~Bq} / \mathrm{kg}$. The range of the calculated air exposure rate was between 14.2 to $228.1 \mathrm{nGy/h}$ in both $0 \mathrm{~m}$ from the Waves and $10 \mathrm{~m}$ from the Waves. The values of external and internal radiation hazard indices are found to be less than unity. Measured natural radioactivity, hazard indices and effective dose received by the population were found to within the recommended limits. This work provides a good baseline data of natural radioactive elements for the sand of the area and its radiological significance.

\section{INTRODUCTION}

Humans have always been exposed to natural radiation arising from the Earth as well as from outside the Earth [1]. All forms of life on earth are exposed to radiation from different sources. The most common sources are from within an outside the solar system, and natural radionuclides in the soil and rocks forming the earth's crust. Natural radionuclides occur in different chemicals forms such as oxides, carbonates, phosphates, sulphates, vanadates and silicates [2]. This environmental background radiation consists of natural and man-made radioactivity. It has been estimated that, on average, $85 \%$ of the radiation to which humans are exposed is from natural sources and $15 \%$ is from man-made sources [3]. It is a well-documented fact that excessive doses of ionizing radiation can hurt human tissues. Natural environmental radioactivity and the related external exposure due to gamma radiation depend mainly on the geological and geographical conditions, and appear at different levels in the soils of each region in the world [4]. Every building construction material contains different quantities of natural radioactive nuclides $[5,6,7]$. Radiation exposure due to building materials can be divided into external and internal exposure [8]. The external exposure is caused by direct gamma radiation, whereas internal exposure is caused by the inhalation of radon $\left({ }^{222} \mathrm{Rn}\right)$, thoron $\left({ }^{220} \mathrm{Rn}\right)$ and their short - lived decay products [9]. Owing to the health risks associated with the exposure to indoor radiation, many governmental and international bodies such as the International Commission on Radiological Protection (ICRP) have adopted measures to minimize such exposures [10]. Radioactivity in soil and sand is one of the main sources of radiation exposure to human beings. Natural radioactivity in soil and sand is mainly due to the presence of the primordial radionuclides ${ }^{238} \mathrm{U},{ }^{232} \mathrm{Th}$, their decay products and ${ }^{40} \mathrm{~K}$. External gamma ray exposure of the body and irradiation of lung tissue from inhalation of radon and its decay products are the main radiological dangers associated with these radionuclides [11]. The annual global average per caput dose from natural background radiation is $2.42 \mathrm{mSv}$, including radon inhalation, cosmic radiations and terrestrial sources [12]. Effective dose equivalent for members of the public varies substantially depending on where they live, their personal and dietary habits, types of buildings materials, etc [13]. The source of the monazite may be traced to the rocks in the area that were weathered and the released minerals were transported by the river and deposited on the coastal areas [14]. Human beings are exposed to low levels of ionizing radiation from natural sources during their daily lives. Naturally occurring 
radioactive materials (NORM) are present in the wider environment such as food, soil, water, air, building materials, including the human body itself (such as ${ }^{40} \mathrm{~K}$ and ${ }^{14} \mathrm{C}$ in bones) [15].

Southwest coast of India is known since long as one of the high level natural background radiation areas in the world [16]. Natural radiation levels in this region are higher than normal which are believed to be emitted from the rich deposits of the monazite bearing beach sands. The mineral monazite contains radioelements, which is the main cause for natural radiation in the southwest coastal belt. The important localities possessing high radioactivity levels along the southwest coastal belt are the ChavaraNeendakara in Kerala coast, and the Manavalakurichi- Kadiapattanam - Midalam in southern TamilNadu Coast. Monazite in beach sands in Kerala and the TamilNadu coastal regions of India has been reported by various investigators [17]. The Knowledge of the level of natural radioactivity in soil is very important for accurately assessing the external exposure and for producing a radiation map of the country.

\section{EXPERIMENTAL TECHNIQUES}

\section{Study area}

The present study area comprised the district Thiruvananthapuram also known as Trivandrum, is the capital of the Indian state of Kerala. Thiruvananthapuram District is the southernmost district of the coastal state of Kerala, in south India. The city is located at $8.5^{\circ} \mathrm{N} 76.9^{\circ} \mathrm{E}$ on the west coast, near the southern tip of mainland India and is bounded by Arabian Sea to its west and the Western Ghats to its east. Thiruvananthapuram district holds a number of tourist spots. The city and the suburbs span an area of $250 \mathrm{~km}^{2}$ (96.53 sq mi). The average elevation of the city is $16 \mathrm{ft}$ above sea level. The district has a population of 3,307,284 (as per the 2011 census) [18]. The mean maximum temperature $34{ }^{\circ} \mathrm{C}$ and the mean minimum temperature is $21^{\circ} \mathrm{C}$. The humidity is high and rises to about $90 \%$ during the monsoon season.

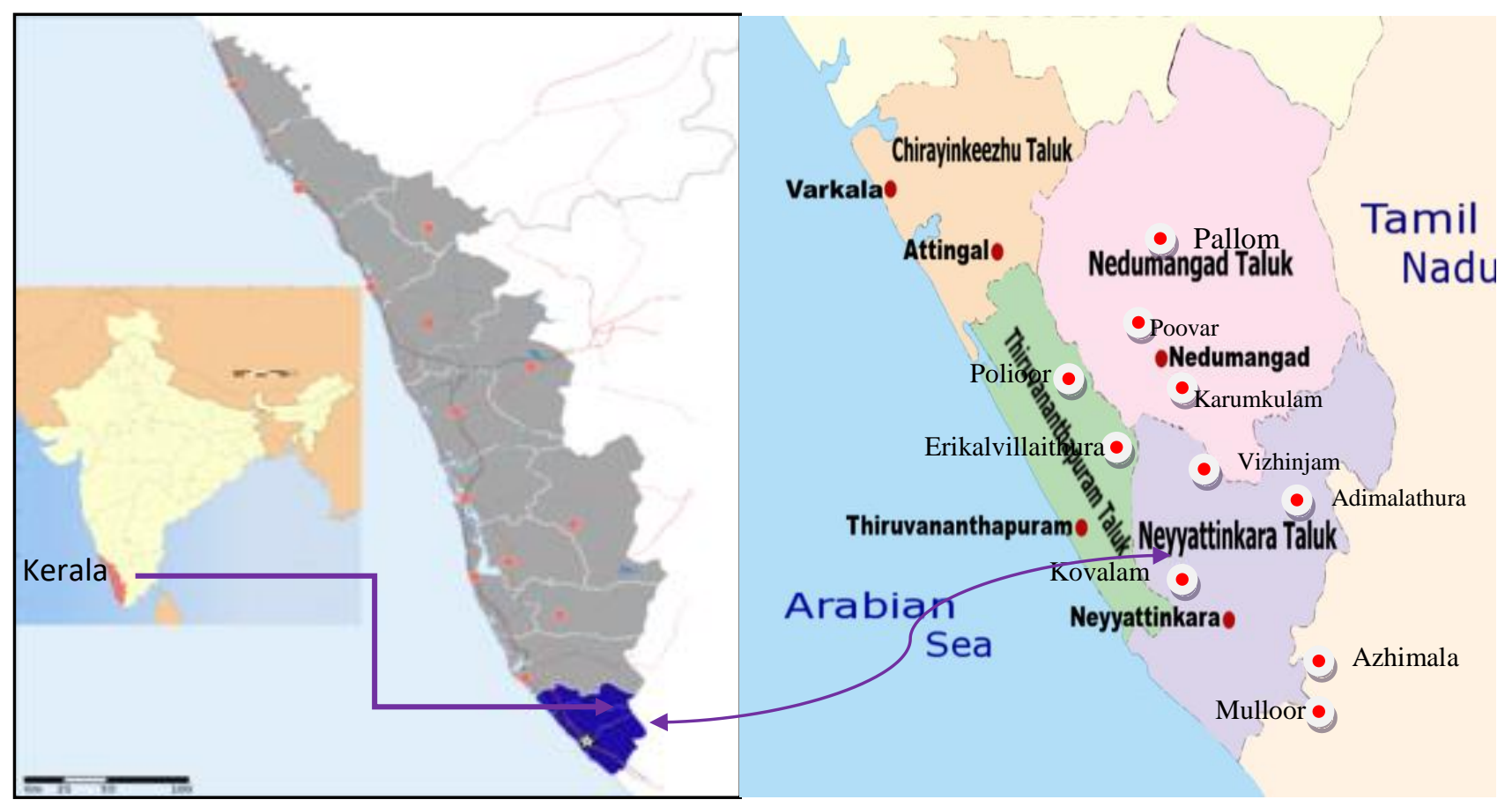

Figure 1: Sampling locations over Kerala coast 


\section{Sampling and Sample Preparation}

A total of 20 beach sand samples were collected randomly from different locations along the west and east coast of southern India (Kerala) during December 2012. At each locations two samples are collected one near the place where the tides reach and the other is on the shore about $10 \mathrm{~m}$ away from the tides. The samples taken at tides reach are named as " $0 \mathrm{~m}$ from the waves" and the samples collected on the shore are named as " $10 \mathrm{~m}$ from the waves".

Soil samples are collected from a pit of $30 \mathrm{~cm}$ length $\mathrm{x} 30 \mathrm{~cm}$ width $\mathrm{x} 15 \mathrm{~cm}$ depth. The dugout samples are uniformly mixed, sieved, air dried and then further dried at temperatures of $100^{\circ} \mathrm{C}$ to $120^{\circ} \mathrm{C}$ for an hour to remove the moisture content. The prepared sample is then stored in an airtight $250 \mathrm{ml}$ plastic container for one month before subjecting them to gamma ray spectral analysis. This is to ensure attaining secular equilibrium between radium and its short- lived daughter products. The net weight of the sample is determined before counting.

\section{Experiment Techniques and Methodology}

\section{Gamma-ray spectrometry}

Gamma spectra from the samples are recorded using HPGe detector coupled to an $8 \mathrm{~K}$ multi- channel analyzer. The spectrometer is calibrated using standard samples supplied by International Atomic Energy Agency, Vienna (IAEA). The minimum detectable activity for ${ }^{232} \mathrm{Th},{ }^{238} \mathrm{U}$ and ${ }^{40} \mathrm{~K}$ are $1.0,3.5$ and 12.25 $\mathrm{Bq} / \mathrm{kg}$ at a back-ground shielding factor of $95 \%$. The analysis of the gamma spectra obtained is performed with dedicated software, and the choice of the reference peak is made in such a way that they are sufficient discriminated. Of the peaks that could be identified via the software, reference is made to that at $1.764 \mathrm{MeV}$ for ${ }^{214} \mathrm{Bi}$, in the ${ }^{238} \mathrm{U}$ decay chain, that at $2.614 \mathrm{MeV}$ for ${ }^{208} \mathrm{Tl}$ in the ${ }^{232} \mathrm{Th}$ decay chain, and one at $1.460 \mathrm{MeV}$ of ${ }^{40} \mathrm{~K}$. Each measurement is performed with a counting time of $10,000 \mathrm{~s}$.

\section{Radium Equivalent Activity}

The Distribution of the natural radionuclide in soil is not uniform. Therefore, Exposure to radiation can be defined in number of terms. Radium Equivalent is one of the widely used hazard indices to compare the activity concentrations of soil containing different amounts of ${ }^{238} \mathrm{U},{ }^{232} \mathrm{Th}$, and ${ }^{40} \mathrm{~K}$.It is the weighted sum of the assumption that $370 \mathrm{~Bq} / \mathrm{kg}$ of ${ }^{238} \mathrm{U}, 259 \mathrm{~Bq} / \mathrm{kg}$ of ${ }^{232} \mathrm{Th}$ and $4810 \mathrm{~Bq} / \mathrm{kg}$ of ${ }^{40} \mathrm{~K}$ produce the same gamma dose rate.

It is calculated by using the formula given by UNSCEAR [3].

$$
\operatorname{Ra}_{\text {eq }}(B q / k g)=A_{U}+1.43 A_{T h}+0.077 A_{K}
$$

Where, $\mathrm{A}_{\mathrm{U}}, \mathrm{A}_{\mathrm{Th}}$ and $\mathrm{A}_{\mathrm{K}}$ are the activity concentration of ${ }^{238} \mathrm{U},{ }^{232} \mathrm{Th}$ and ${ }^{40} \mathrm{~K}$ respectively.

\section{External Gamma Absorbed Dose Rate}

The gamma dose rate (D) in $\mathrm{nGy} \cdot \mathrm{h}^{-1}$ in the outdoor air at $1 \mathrm{~m}$ above the ground surface for the uniform distribution of radionuclides ${ }^{238} \mathrm{U},{ }^{232} \mathrm{Th}$ and ${ }^{40} \mathrm{~K}$ was computed on the basis of guidelines provided by UNSCEAR 2000 is calculated using the following equation .

$$
D=0.462 A_{U}+0.624 A_{T h}+0.0417 A_{K}
$$

Where, $D$ is the dose rate in $\mathrm{nGy} \cdot \mathrm{h}^{-1}$ and $A_{\mathrm{U}}, A_{\mathrm{Th}}$ and $A_{\mathrm{K}}$ are the activity concentration $\left(\mathrm{Bq} \cdot \mathrm{kg}^{-1}\right)$ of ${ }^{238} \mathrm{U}$, ${ }^{232} \mathrm{Th}$ and ${ }^{40} \mathrm{~K}$, respectively [19]. 


\section{Annual External Dose Equivalent}

To measure the annual effective external dose equivalent, considerations must be made for the conversion coefficient from the absorbed dose rate in air to the effective dose and the outdoor occupancy factor. The conversion coefficient $0.7 \mathrm{SvGy}^{-1}$, was recommended by the United Nations Scientific Committee on the Effects of Atomic Radiation. The adult spend $\sim 20 \%$ of their time in outdoors. Therefore, the outdoor occupancy factor was given by 0.2 .

\section{AEED $=D(n G y / h) \times T \times D C F\left(S v G y^{-1}\right) \times O F$}

Where, $\quad$ AEED $=D(\mathrm{nGy} / \mathrm{h}) \times 8760\left(\mathrm{hy}^{-1}\right) \times 0.7\left(\mathrm{SvGy}^{-1}\right) \times 0.2 \times 10^{-3}$

$\mathrm{D}$ is the absorbed gamma dose rate, DCF is the dose conversion Factor, OF is the outdoor occupancy factor and $\mathrm{T}$ is the time for a year [20].

\section{Annual Gonald Dose Equivalent}

The annual gonadal dose equivalent $(\mathrm{G}, \mu \mathrm{Sv} / \mathrm{yr})$ due to ${ }^{238} \mathrm{U},{ }^{232} \mathrm{Th}$ and ${ }^{40} \mathrm{~K}$ activity concentration was calculated using the following relation.

$$
\mathrm{AGDE}=3.09 \mathrm{~A}_{\mathrm{U}}+4.18 \mathrm{~A}_{\mathrm{Th}}+0.314 \mathrm{~A}_{\mathrm{K}}
$$

Where, $A_{\mathrm{U}}, A_{\mathrm{Th}}$ and $A_{\mathrm{K}}$ are the activity concentration (Bq.kg $\left.{ }^{-1}\right)$ of ${ }^{238} \mathrm{U},{ }^{232} \mathrm{Th}$ and ${ }^{40} \mathrm{~K}$, respectively [21].

\section{External Hazard index}

The external hazard index $\mathrm{H}_{\mathrm{ex}}$ estimates the potential radiological hazard posed by different samples. It is a dimensionless quantity and a safety criterion for materials is that $\mathrm{H}_{\mathrm{ex}} \leq 1$

$$
H_{e x}=\frac{A_{U}}{370 B q / k g}+\frac{A_{T h}}{258 B q / k g}+\frac{A_{K}}{4810 B q / k g}
$$

Where,

$\mathrm{A}_{\mathrm{U}}, \mathrm{A}_{\mathrm{Th}}$ and $\mathrm{A}_{\mathrm{K}}$ are the activity concentration of ${ }^{238} \mathrm{U},{ }^{232} \mathrm{Th}$ and ${ }^{40} \mathrm{~K}$ respectively.

\section{Internal Hazard index}

The external hazard index $\mathrm{H}_{\text {in }}$ estimates the internal exposure to radon and its daughter products different samples. It is a dimensionless quantity and a safety criterion for materials is that $\mathrm{H}_{\mathrm{in}} \leq 1$

$$
H_{\text {in }}=\frac{A_{U}}{185 B q / k g}+\frac{A_{T h}}{259 B q / k g}+\frac{A_{K}}{4810 B q / k g}
$$

Where,

$\mathrm{A}_{\mathrm{U}}, \mathrm{A}_{\mathrm{Th}}$ and $\mathrm{A}_{\mathrm{K}}$ are the activity concentration of ${ }^{238} \mathrm{U},{ }^{232} \mathrm{Th}$ and ${ }^{40} \mathrm{~K}$ respectively [20]. 


\section{RESULT AND DISCUSSIONS}

Table 1. Activity Concentration of Potassium -40

\begin{tabular}{|l|c|c|c|}
\hline \multirow{2}{*}{\multicolumn{1}{c|}{ Location }} & \multicolumn{3}{c|}{ Activity Concentration of K-40 (Bq/kg) } \\
\cline { 2 - 4 } & $\begin{array}{c}0 \mathrm{~m} \text { from the } \\
\text { waves }\end{array}$ & $\begin{array}{c}10 \mathrm{~m} \text { from the } \\
\text { waves }\end{array}$ & $\begin{array}{c}\text { Ratio }=0 \mathrm{~m} \text { from } \\
\text { the waves/10 } \mathrm{m} \\
\text { from the waves }\end{array}$ \\
\hline Pallom & $154.45 \pm 11.47$ & $46.14 \pm 10.95$ & 3.4 \\
\hline Polioor & $134.72 \pm 15.38$ & $25.69 \pm 12.05$ & 5.2 \\
\hline Erikalvillaithura & $133 \pm 10.98$ & $24.09 \pm 11.01$ & 5.5 \\
\hline Kovalam & $51.08 \pm 10.7$ & $37.82 \pm 12.06$ & 1.4 \\
\hline Mulloor & $71.54 \pm 11.07$ & $17.691 \pm 12.71$ & 4.0 \\
\hline Azhimala & $151.94 \pm 12.09$ & $88.73 \pm 11.13$ & 1.6 \\
\hline Adimalathura & $92.21 \pm 10.80$ & $60.97 \pm 11.42$ & 1.5 \\
\hline Vizhinjam & $66.27 \pm 9.36$ & $30.56 \pm 18.09$ & 2.2 \\
\hline Karumkulam & $103.89 \pm 10.28$ & $35.5 \pm 11.19$ & 2.4 \\
\hline Poovar & $99.27 \pm 10.99$ & $42.62 \pm 10.22$ & 2.8 \\
\hline Mean & $108.35 \pm 11.31$ & $40.98 \pm 12.08$ & 3.0 \\
\hline STANDARD DEVIATION & $61.94 \pm 1.59$ & $20.86 \pm 2.22$ & 1.5 \\
\hline Geometric mean & 99.7 & 37.0 & 2.7 \\
\hline Geometric Standard Deviation & 1.5 & 1.9 & 1.7 \\
\hline
\end{tabular}

Table 2. Activity Concentration of Uranium-238

\begin{tabular}{|l|c|c|c|}
\hline \multirow{2}{*}{\multicolumn{1}{|c|}{ Location }} & \multicolumn{3}{|c|}{ Activity Concentration of U-238 (Bq/kg) } \\
\cline { 2 - 4 } & $\begin{array}{c}0 \mathrm{~m} \text { from } \\
\text { the waves }\end{array}$ & $\begin{array}{c}10 \mathrm{~m} \text { from the } \\
\text { waves }\end{array}$ & $\begin{array}{c}\text { Ratio=0 m from the } \\
\text { waves/10 m from the } \\
\text { waves }\end{array}$ \\
\hline Pallom & $6.69 \pm 1.53$ & $8.30 \pm 2.41$ & 0.8 \\
\hline Polioor & $15.79 \pm 2.58$ & $8.86 \pm 2.71$ & 1.8 \\
\hline Erikalvillaithura & $3.92 \pm 1.31$ & $8.74 \pm 2.49$ & 0.5 \\
\hline Kovalam & $28.11 \pm 2.68$ & $16.18 \pm 2.35$ & 1.7 \\
\hline Mulloor & $20.52 \pm 2.37$ & $13.36 \pm 3.05$ & 1.5 \\
\hline Azhimala & $8.25 \pm 1.71$ & $5.25 \pm 2.38$ & 1.7 \\
\hline Adimalathura & $10.30 \pm 1.77$ & $7.43 \pm 2.50$ & 1.4 \\
\hline Vizhinjam & $100.34 \pm 1.38$ & $73.70 \pm 4.66$ & 1.4 \\
\hline Karumkulam & $13.45 \pm 1.86$ & $7.51 \pm 2.50$ & 3.1 \\
\hline Poovar & $81.88 \pm 4.27$ & $4.40 \pm 2.22$ & 10.9 \\
\hline Mean & $28.90 \pm 2.45$ & $15.37 \pm 2.72$ & 2.5 \\
\hline Standard Deviation & $33.70 \pm 1.08$ & $20.79 \pm 0.71$ & 3.0 \\
\hline Geometric mean & 17.2 & 10.3 & 1.7 \\
\hline Geometric Standard Deviation & 2.8 & 2.2 & 2.3 \\
\hline
\end{tabular}


Table 3. Activity Concentration of Thorium-232

\begin{tabular}{|l|c|c|c|}
\hline \multirow{2}{*}{\multicolumn{1}{c|}{ Location }} & \multicolumn{3}{|c|}{ Activity Concentration of Th-232 (Bq/kg) } \\
\cline { 2 - 4 } & $\begin{array}{c}\text { O m from the } \\
\text { waves }\end{array}$ & $\begin{array}{c}10 \mathrm{~m} \text { from the } \\
\text { waves }\end{array}$ & $\begin{array}{c}\text { Ratio=0 m from the } \\
\text { waves/10 m from the } \\
\text { waves }\end{array}$ \\
\hline Pallom & $13.52 \pm 3.25$ & $10.97 \pm 2.07$ & 1.2 \\
\hline Polioor & $18.58 \pm 4.65$ & $17.92 \pm 2.38$ & 1.0 \\
\hline Erikalvillaithura & $16.86 \pm 3.25$ & $18.21 \pm 2.18$ & 0.9 \\
\hline Kovalam & $55.09 \pm 4.21$ & $38.7 \pm 4.41$ & 1.4 \\
\hline Mulloor & $70.09 \pm 4.50$ & $75.29 \pm 2.96$ & 0.9 \\
\hline Azhimala & $16.07 \pm 3.51$ & $11.89 \pm 2.09$ & 1.4 \\
\hline Adimalathura & $9.15 \pm 3.19$ & $14.05 \pm 2.18$ & 0.7 \\
\hline Vizhinjam & $296.27 \pm 6.62$ & $274.12 \pm 4.63$ & 1.1 \\
\hline Karumkulam & $11.92 \pm 3.04$ & $16.56 \pm 2.19$ & 1.9 \\
\hline Poovar & $227.06 \pm 6.43$ & $6.36 \pm 1.91$ & 13.7 \\
\hline Mean & $73.46 \pm 4.26$ & $48.4 \pm 2.70$ & 2.4 \\
\hline Standard Deviation & $102.52 \pm 1.32$ & $81.85 \pm 1.00$ & 4.0 \\
\hline Geometric mean & 33.8 & 23.5 & 1.4 \\
\hline Geometric Standard Deviation & 3.5 & 3.0 & 0.4 \\
\hline
\end{tabular}

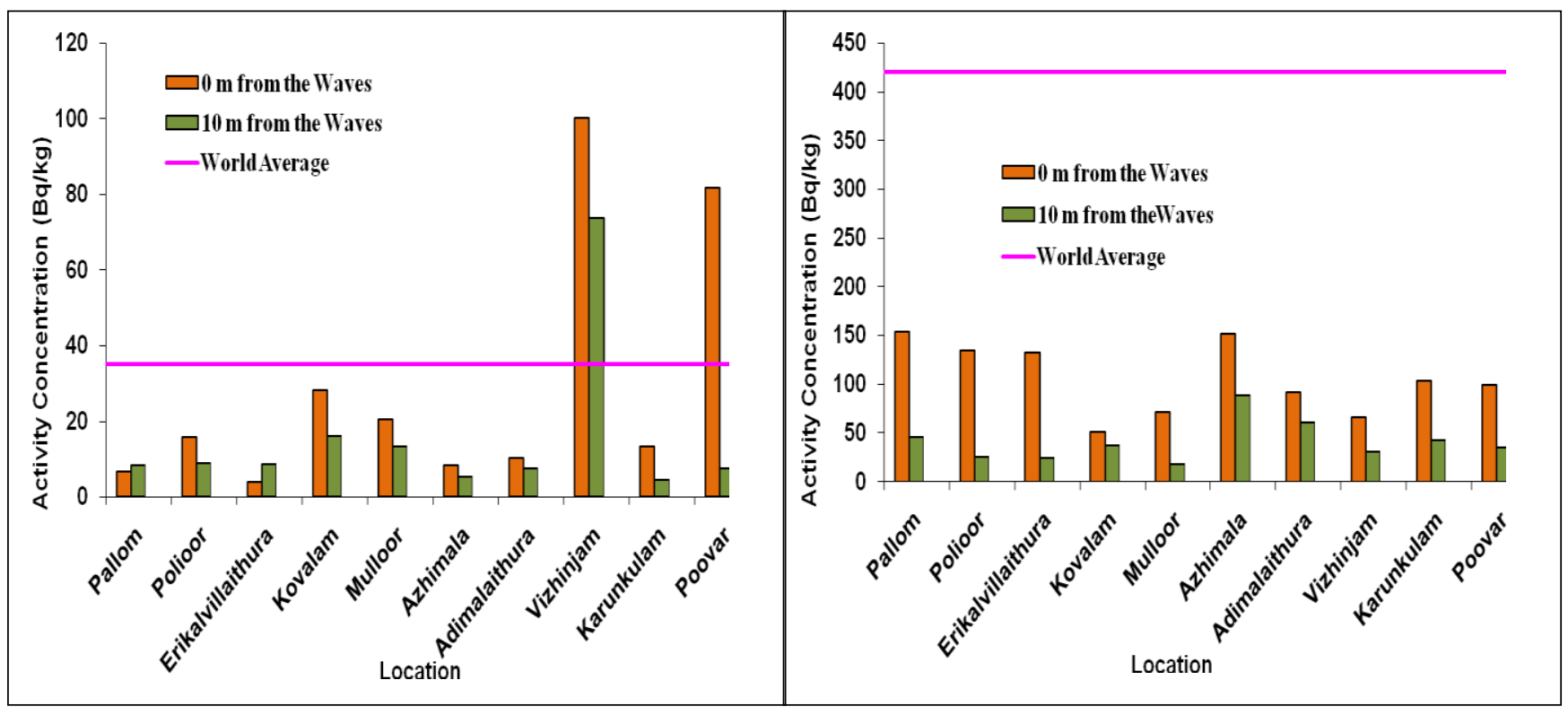




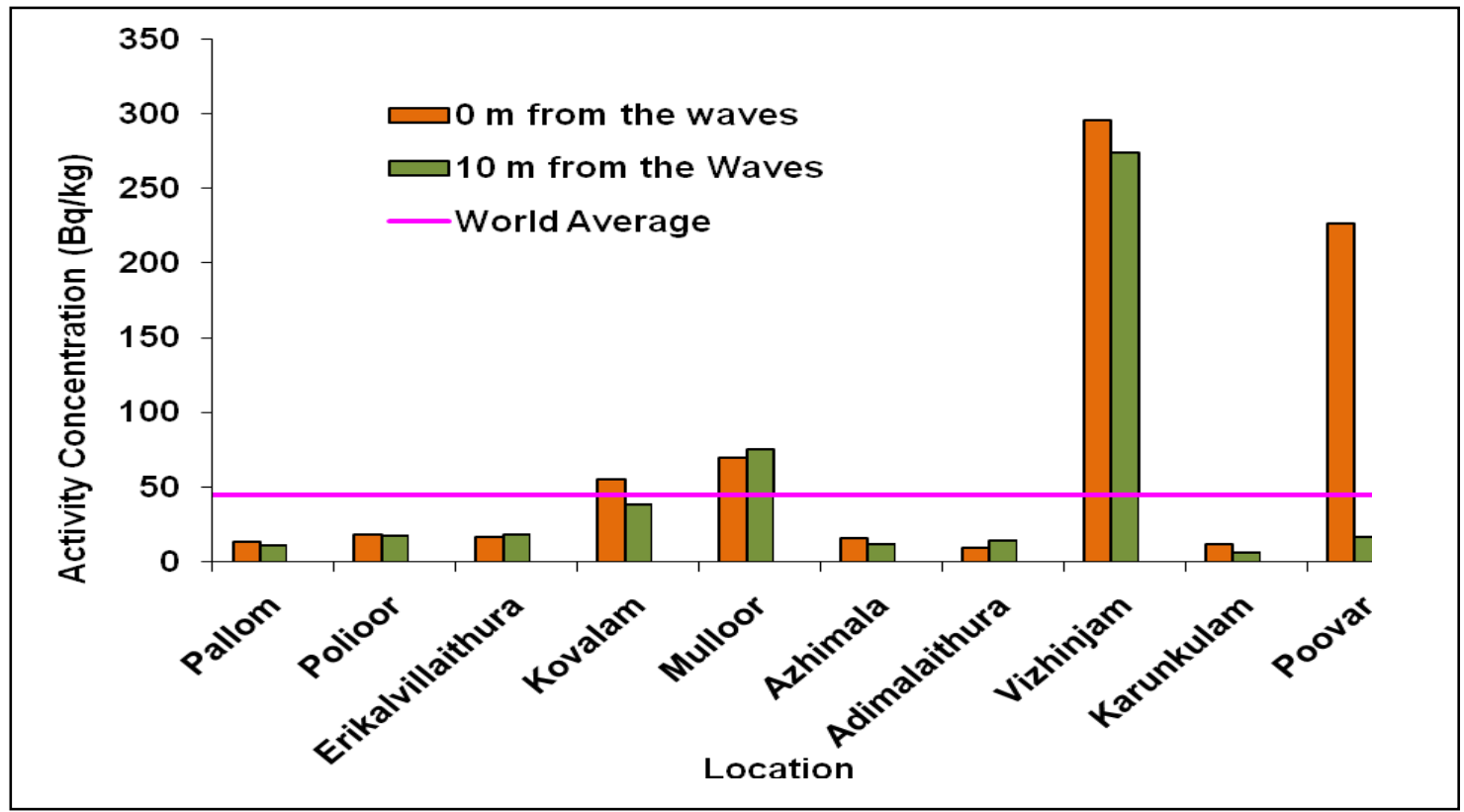

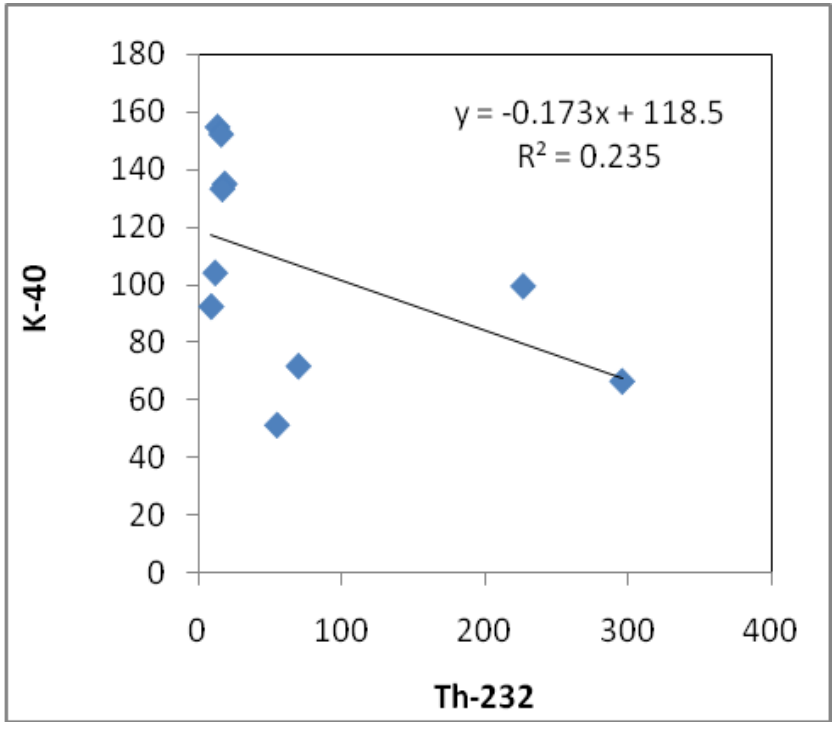

Graph 2a. Correlation between ${ }^{40} \mathrm{~K}-{ }^{238} \mathrm{U}$

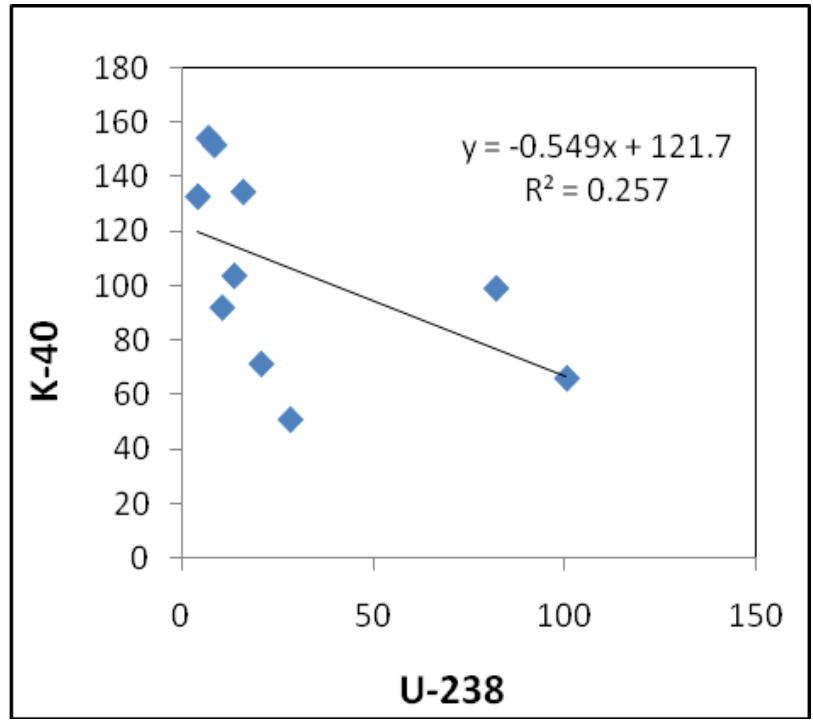

Graph 2b. Correlation between ${ }^{40} \mathrm{~K}-{ }^{232} \mathrm{Th}$ 


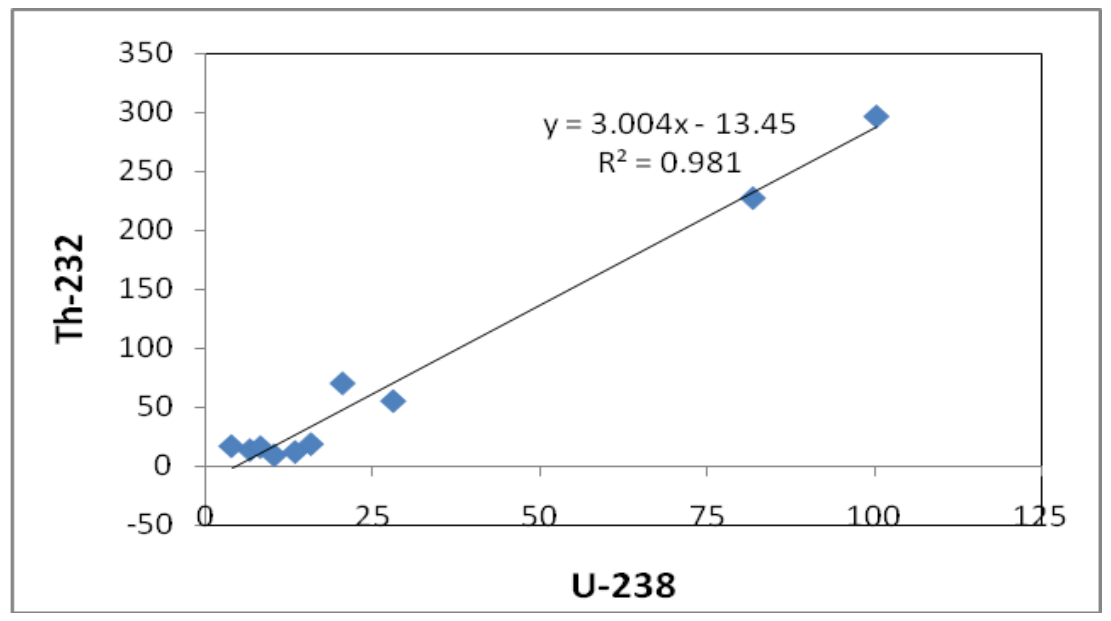

Graph 3. Correlation between ${ }^{238} \mathrm{U}$ and ${ }^{232}$ Th content

Table 4. Measured values of Radiological Indices in $0 \mathrm{~m}$ from the waves locations

\begin{tabular}{|c|c|c|c|c|c|c|}
\hline Location & $\begin{array}{c}\text { Radium Equivalent } \\
\left(\mathrm{Ra}_{\mathrm{eq})} \mathrm{Bq} / \mathrm{kg}\right.\end{array}$ & $\begin{array}{c}\text { Absorbed Dose(D) } \\
\mathrm{nGy} / \mathrm{hr}\end{array}$ & $\begin{array}{c}\text { AEED } \\
\mu \mathrm{Sv} / \mathrm{yr}\end{array}$ & $\begin{array}{c}\text { AGDE } \\
\mu \mathrm{Sv} / \mathrm{yr}\end{array}$ & $\mathrm{H}_{\mathrm{ex}}$ & $\mathrm{H}_{\text {in }}$ \\
\hline Pallom & 37.9 & 17.7 & 21.8 & 125.7 & 0.1 & 0.2 \\
\hline Polioor & 52.7 & 24.2 & 29.6 & 168.8 & 0.1 & 0.3 \\
\hline Erikalvillathura & 38.3 & 17.6 & 21.6 & 124.3 & 0.1 & 0.2 \\
\hline Kovalam & 110.9 & 48.4 & 59.4 & 333.2 & 0.3 & 0.7 \\
\hline Mulloor & 126.3 & 54.8 & 67.2 & 378.8 & 0.3 & 0.9 \\
\hline Azhimala & 42.9 & 19.9 & 24.4 & 140.4 & 0.1 & 0.3 \\
\hline Adimalathura & 30.5 & 14.2 & 17.4 & 99.0 & 0.1 & 0.2 \\
\hline Vizhinjam & 529.1 & 228.1 & 279.7 & 1569.3 & 1.4 & 3.7 \\
\hline Karumkulam & 38.5 & 17.8 & 21.8 & 124.0 & 0.1 & 0.2 \\
\hline Poovar & 414.2 & 179.1 & 219.7 & 1233.3 & 1.1 & 2.9 \\
\hline
\end{tabular}

Table 5. Measured values of Radiological Indices in $10 \mathrm{~m}$ from the waves locations

\begin{tabular}{|c|c|c|c|c|c|c|}
\hline Location & $\begin{array}{c}\text { Radium Equivalent } \\
\left(\mathrm{Ra}_{\mathrm{eq}} \mathrm{Bq} / \mathrm{kg}\right.\end{array}$ & $\begin{array}{c}\text { Absorbed Dose(D) } \\
\mathrm{nGy} / \mathrm{hr}\end{array}$ & $\begin{array}{c}\mathrm{AEED} \\
\mu \mathrm{Sv} / \mathrm{yr}\end{array}$ & $\begin{array}{c}\mathrm{AGDE} \\
\mu \mathrm{Sv} / \mathrm{yr}\end{array}$ & $\mathrm{H}_{\mathrm{ex}}$ & $\mathrm{H}_{\text {in }}$ \\
\hline Pallom & 27.5 & 12.4 & 15.2 & 86.0 & 0.1 & 0.2 \\
\hline Polioor & 36.5 & 16.0 & 19.6 & 110.3 & 0.1 & 0.2 \\
\hline Erikalvillathura & 36.6 & 16.0 & 19.7 & 110.7 & 0.1 & 0.2 \\
\hline Kovalam & 74.4 & 32.4 & 39.8 & 223.6 & 0.2 & 0.5 \\
\hline Mulloor & 122.4 & 52.4 & 64.3 & 361.5 & 0.3 & 0.9 \\
\hline Azhimala & 29.1 & 13.3 & 16.4 & 93.8 & 0.1 & 0.2 \\
\hline Adimalathura & 32.2 & 14.5 & 17.8 & 100.8 & 0.1 & 0.2 \\
\hline Vizhinjam & 468.0 & 200.9 & 246.4 & 1383.2 & 1.3 & 3.3 \\
\hline Karumkulam & 33.9 & 15.0 & 18.4 & 103.6 & 0.1 & 0.2 \\
\hline Poovar & 16.8 & 7.7 & 9.4 & 53.6 & 0.0 & 0.1 \\
\hline
\end{tabular}




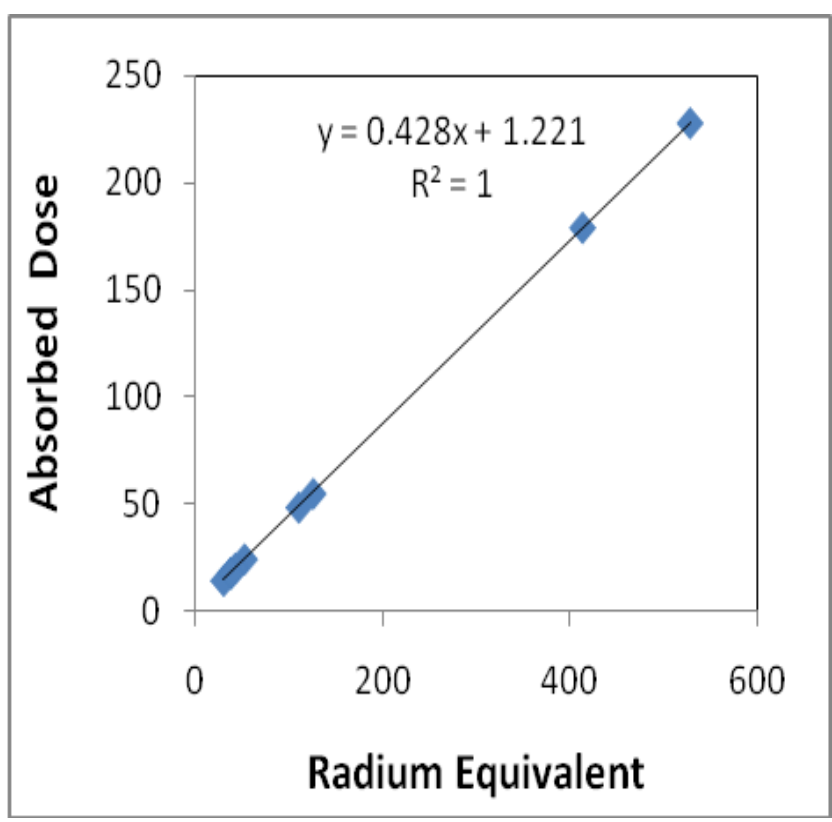

Graph 4a. Correlation between Absorbed dose and Radium Equivalent of $0 \mathrm{~m}$ from the Waves

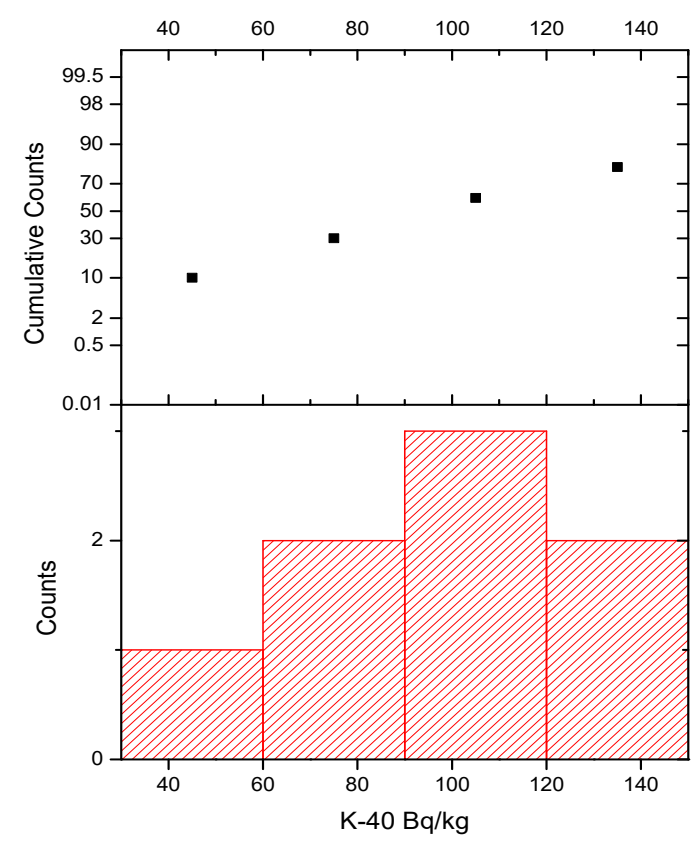

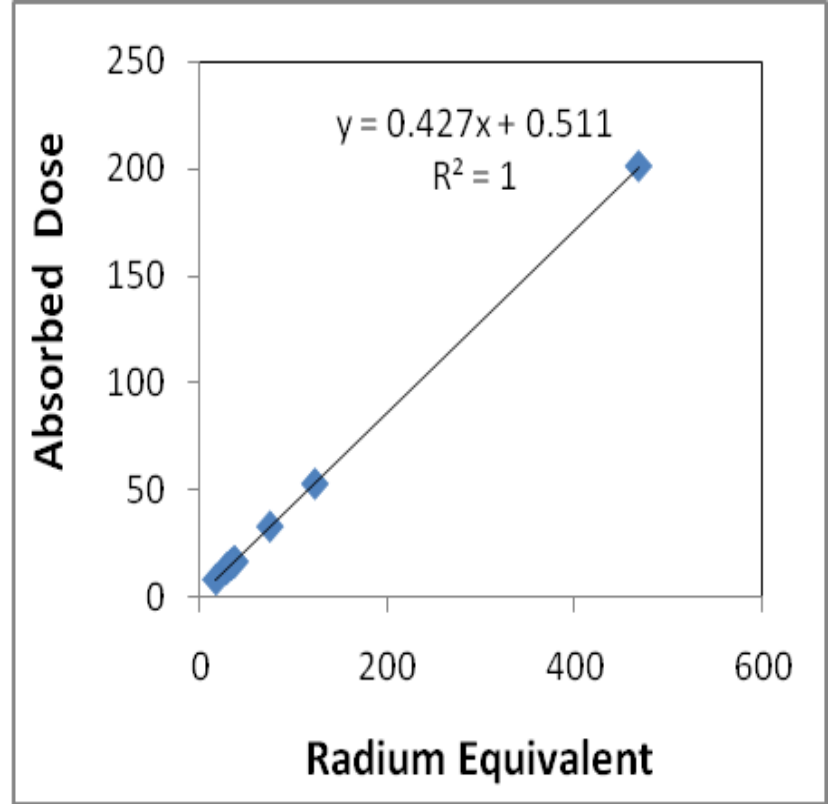

Graph 4b. Correlation between Absorbed dose and Radium Equivalent both of $10 \mathrm{~m}$ from waves

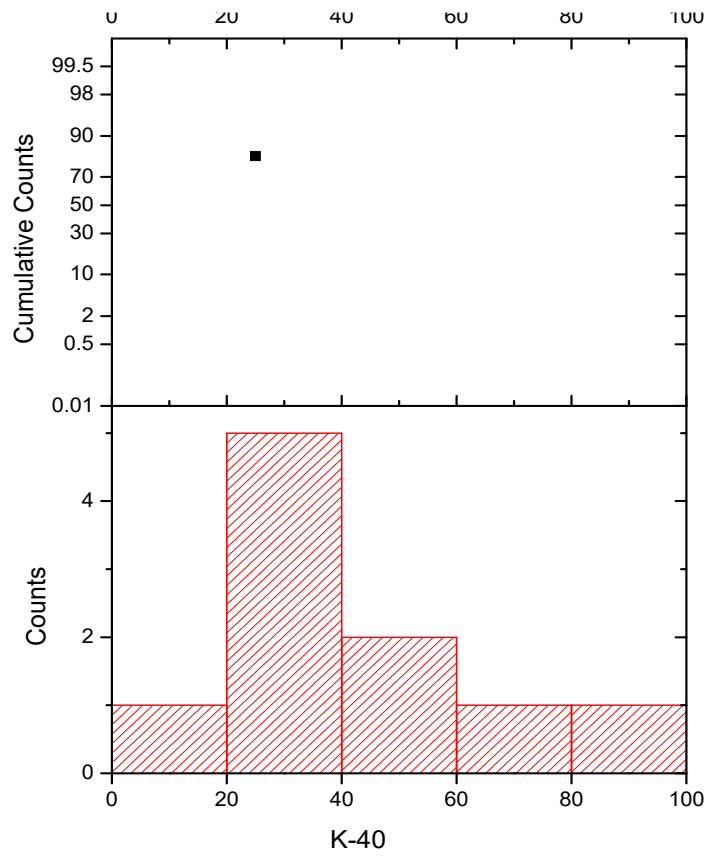

Graph 5. Histograms and cumulative frequency histograms of ${ }^{40} \mathrm{~K}$ in $0 \mathrm{~m}$ and $10 \mathrm{~m}$ from waves 

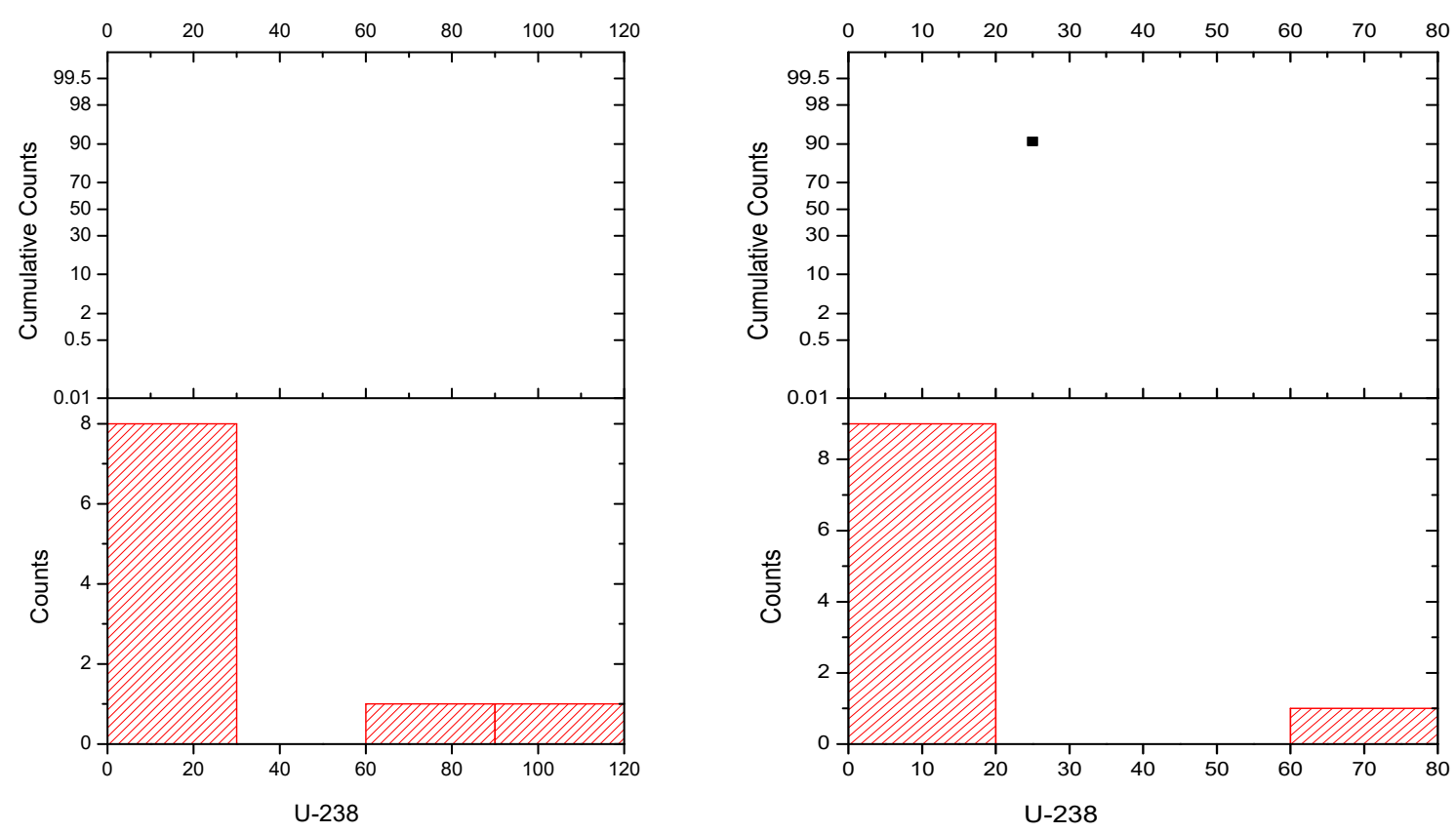

Graph 6. Histograms and cumulative frequency histograms of ${ }^{238} \mathrm{U}$ in $\mathbf{0} \mathrm{m}$ and $10 \mathrm{~m}$ from waves
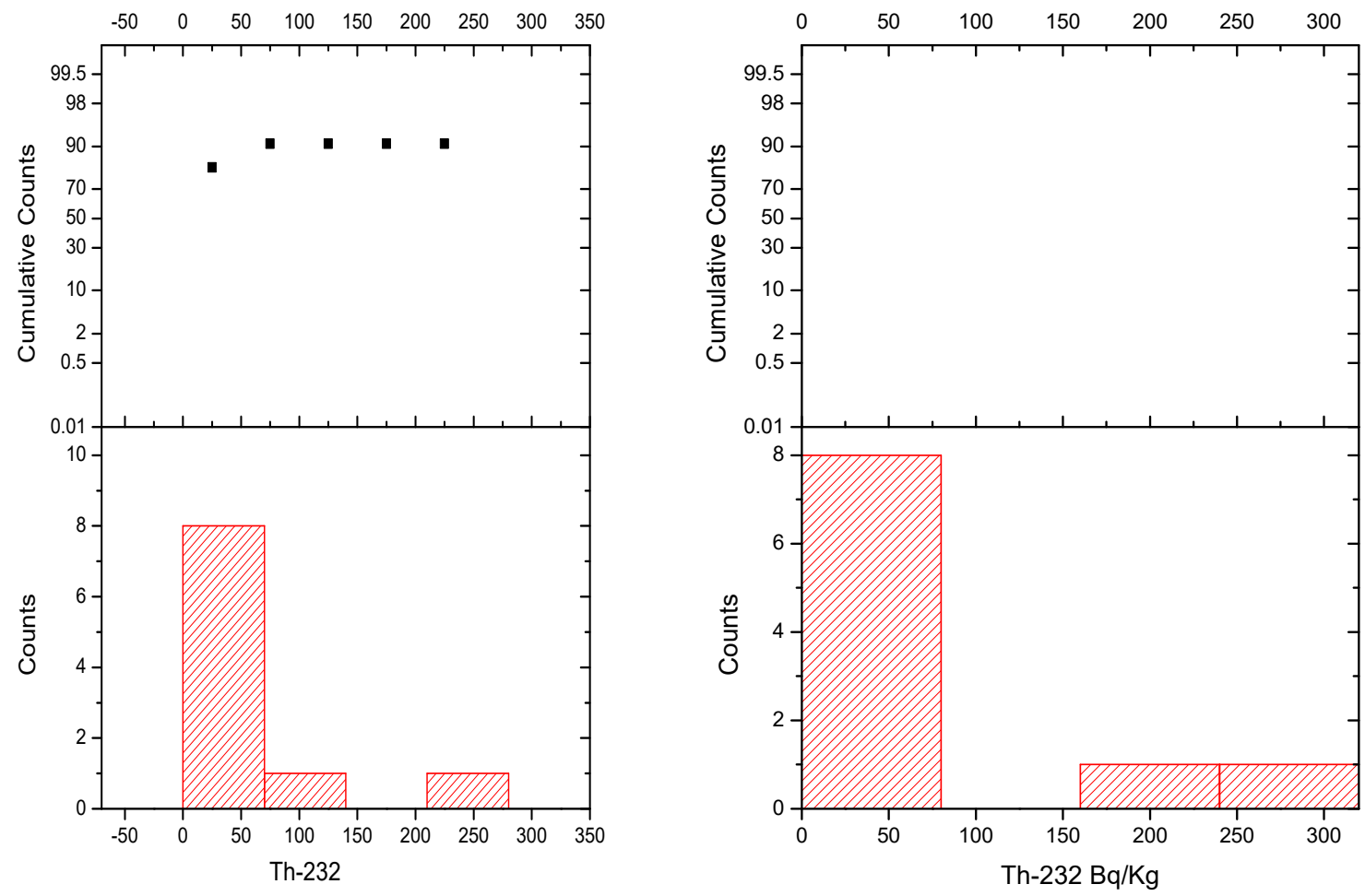

Graph 7. Histograms and cumulative frequency histograms of ${ }^{432} \mathrm{Th}$ of in $0 \mathrm{~m}$ and $10 \mathrm{~m}$ from waves 
The activity concentrations ${ }^{40} \mathrm{~K}{ }^{238} \mathrm{U}$, and ${ }^{232} \mathrm{Th}(\mathrm{Bq} / \mathrm{kg})$ are estimated and given in Table $1-3$. The activity of ${ }^{40} \mathrm{~K}$ in $0 \mathrm{~m}$ from the waves is more (1.5 to 5.5 times) than the activity at $10 \mathrm{~m}$ from the waves locations. The activity of ${ }^{40} \mathrm{~K}$ along the $0 \mathrm{~m}$ from the waves is in the range 51 to $154 \mathrm{~Bq} / \mathrm{kg}$. Along the 10 $\mathrm{m}$ from the waves the variation observed is in the range of 17 to $88 \mathrm{~Bq} / \mathrm{kg}$. Overall measured ${ }^{40} \mathrm{~K}$ activity is in the range 17 to $154 \mathrm{~Bq} / \mathrm{kg}$. When compared with UNSCEAR reported range $140-850 \mathrm{~Bq} / \mathrm{kg}$ the 10 $\mathrm{m}$ from the waves sample activities are lesser than the minimum value of UNSCEAR. But the $0 \mathrm{~m}$ from the waves sample values are closure the UNSCEAR minimum values. The $0 \mathrm{~m}$ from the waves samples showed Geometric Mean of $99.68 \mathrm{~Bq} / \mathrm{kg}$ with Geometric Standard Deviation of $1.45 \mathrm{~Bq} / \mathrm{kg}$. The $10 \mathrm{~m}$ from the waves samples had Geometric Mean of 36.98 with Geometric Standard Deviation of 1.59. In general the values ${ }^{238} \mathrm{U}$ at $10 \mathrm{~m}$ from the waves are lesser than that of near $0 \mathrm{~m}$ from the waves. The near $0 \mathrm{~m}$ from the waves activity has Geometric Mean of $17.88 \mathrm{~Bq} / \mathrm{kg}$ with Geometric Standard Deviation of $2.83 \mathrm{~Bq} / \mathrm{kg}$ and range is 4 to $100 \mathrm{~Bq} / \mathrm{kg}$. The $10 \mathrm{~m}$ from the waves sample activity has Geometric Mean of $10.28 \mathrm{~Bq} / \mathrm{kg}$ with Geometric Standard Deviation of $2.20 \mathrm{~Bq} / \mathrm{kg}$ and range is 4 to $74 \mathrm{~Bq} / \mathrm{kg}$. The observed activity range is within the UNSCEAR reported range 16 to $110 \mathrm{~Bq} / \mathrm{kg}$. Except Poovar, at all other locations the ${ }^{232} \mathrm{Th}$ activity at $10 \mathrm{~m}$ from the waves locations is closer to that of near $0 \mathrm{~m}$ from the waves. At Poovar, the near $0 \mathrm{~m}$ from the waves activity of is 14 times more than that of $10 \mathrm{~m}$ from the waves activity. The UNSCEAR reported ${ }^{232} \mathrm{Th}$ activity range is 11 to $64 \mathrm{~Bq} / \mathrm{kg}$. The near $0 \mathrm{~m}$ from the waves activity at Poovar is higher than this range. But at other locations the activities are within this range. At Vizhinjam both $0 \mathrm{~m}$ from the waves and $10 \mathrm{~m}$ from the waves activities are higher than the maximum values reported by UNSCEAR as well as for India (14-160 Bq/kg).

This energy range is sufficient to cover all the natural gamma emitters in the samples. Graph 1 shows a comparison between $0 \mathrm{~m}$ from the waves and $10 \mathrm{~m}$ from the waves for natural radionuclides in different locations and it is compared to the world average value reported in the UNSCEAR report. The presence of each radionuclide in the soil and the variation in concentration depend on the level of the soil and this reveals the nature of the soil presented in the study area. The range of concentrations of ${ }^{238} \mathrm{U}$ and ${ }^{232} \mathrm{Th}$ were nearly similar and lowest, while ${ }^{40} \mathrm{~K}$ showed the highest values. A negative correlation exists between ${ }^{40} \mathrm{~K}-{ }^{238} \mathrm{U}$ and ${ }^{40} \mathrm{~K}-{ }^{232} \mathrm{Th}$ as shown in Graph. 2a \& 2b. A strong positive correlation exists between ${ }^{238} \mathrm{U}$ and ${ }^{232} \mathrm{Th}(\mathrm{R}=0.98)$ in beach sand samples as shown in Graph.3, indicating the presence of monazite in beach sand samples. As shown in Graph. 4a \& 4b a strong correlation exists between Radium Equivalent and Air Absorbed Dose Rate due to the same origin. The activity concentrations of the three natural radionuclides $\left({ }^{238} \mathrm{U},{ }^{232} \mathrm{Th}\right.$ and $\left.{ }^{40} \mathrm{~K}\right)$ plotted as histograms and cumulative frequency distribution are presented in Graph. 5-7. The histogram shows centre, spread, skewness and modes in the data of individual radionuclides. The cumulative histogram ${ }^{40} \mathrm{~K}$ only distributed normally in $0 \mathrm{~m}$ from the waves, while the distribution of ${ }^{238} \mathrm{U}$ and ${ }^{232} \mathrm{Th}$ are skewed.

Average value of radium equivalent activity is 142.12 in $0 \mathrm{~m}$ from the waves $\mathrm{Bq} / \mathrm{kg}$ and $82.74 \mathrm{~Bq} / \mathrm{kg}$ in $10 \mathrm{~m}$ from the waves, which is below the threshold value of $370 \mathrm{~Bq} / \mathrm{kg}$. The range of the calculated air exposure rate at $0 \mathrm{~m}$ from the waves is between 14.2 to $228.1 \mathrm{nGy} / \mathrm{h}$. At $10 \mathrm{~m}$ from the waves the calculated air exposure rate is ranging between 7 to $200 \mathrm{nGy} / \mathrm{h}$. Based on the calculated air exposure rate values, all the sampling locations of Kerala in the present study fall under normal background radiation area. The annual effective dose equivalent (AEED) and annual gonald dose equivalent (AGDE) were calculated by using UNSCEAR report. The annual effective dose both in $0 \mathrm{~m}$ from the waves and $10 \mathrm{~m}$ from the waves lies in the range of $9.4-279.73 \mu \mathrm{Sv} / \mathrm{yr}$. The annual gonald dose equivalent varies from $53.56-1569.27 \mu \mathrm{Sv} / \mathrm{yr}$. The external and internal hazard indices are found to be in the range of $0.10-$ 3.68. As the activity concentrations, the radium equivalent activity and the internal and external hazard indices of the soil samples reported in this study area are within the acceptable limit in Table $4 \& 5$. 


\section{CONCLUSION}

The activity concentration of naturally occurring radionuclides in twenty beach sand samples collected from Thiruvanathapuram, Kerala has been estimated using HPGe based gamma ray spectrometer. The values of the activity concentrations of ${ }^{238} \mathrm{U},{ }^{232} \mathrm{Th}$ and ${ }^{40} \mathrm{~K}$ are "Within the world average value". It is observed that thorium is abundant than any other radionuclide, which is due to the monazite present in the primary sand. The external and internal hazard indices show that the soil from Thiruvanathapuram can be regarded as hazard free. The data for activity concentration exhibits a positive correlation between ${ }^{238} \mathrm{U}$ $a^{232} \mathrm{Th}$. The values of external and internal radiation hazard indices are found to be less than unity. Measured values were compared with literature reported values. The radiological hazard indices are calculated. The measurement taken in this study represents a base line data base of activity levels that can be served as a reference point for future studies.

\section{REFERENCES}

1. Pyle, G.G. and Clulow, F. V. Radionuclide equilibria between the aquatic environment and fish tissues. J. Environ. Radioact. 40(1), 59-74(1998).

2. Isinkaye, M. O. Radiometric assessment of natural radioactivity levels of bituminous soil in Agbabu, southwest Nigeria. Radiat. Meas. 43, 125-128 (2008).

3. UNSCEAR (United Nations Scientific Committee on the Effects of Atomic Radiation). Sources and biological effects of ionizing radiation annex $b$ : exposures from natural radiation sources. (2000).

4. Crawford-Brown, D.J. The biokinetics and dosimetry of radon-222 in the human body following ingestion of groundwater. Environ. Geochem. Health 11(1), 10-17 (1989).

5. Duenas, C., Fernandez, M.C., Carretero, J. and Liger, E. Natural radioactivity levels in Andalusian spas. Water Res. 32 (8), 2271-2278 (1998).

6. International Agency for Research on Cancer. Ionizing radiation, Part 2: Some internally deposited radionuclides. Vol. 78. IARC (2001).

7. Mays, C.W. and Rowland, R.E. Cancer risk from the lifetime intake of Ra and U isotopes. Health Phys. 48 (5), 635-647 (1985).

8. Oznur, O. Investigation of some parameters of collector chamber method for determination of radium-226. M.Sc thesis (Turkish with English abstract), p. 61 (1993).

9. Vinson, D.S., Campbell, T.R. and Vengosh, A. Radon transfer from groundwater used in showers to indoor air. Appl. Geochem. 23, 2676-2685 (2008).

10. International Commission on Radiological Protection Publication 39 (ICRP). Principles for limiting exposure of the pubic to natural sources of radiation. Ann. ICRP 14 (1) (1984).

11. Withanage, A.P., and Mahawatte, P. Radioactivity of beach sand in the south western coast of Sri Lanka. Radiat. Prot. Dosim. 153 (3), 384-389 (2013).

12. Hu, Q-H., Weng, J-Q. and Wang, J-S. Sources of anthropogenic radionuclides in the environment: a review. J. Environ. Radioact. 101, 426-437 (2010). 
13. Sivakumar, R., Selvasekarapandian, S., Muguntha Manikandan, N. and Raghunath, V.M. Natural indoor gamma background in Coonoor environment of south India. J. Radional. Nucl. Chem. 252(2), 413-419 (2002).

14. Al-Jundi, J., Al-Bataina, B.A., Abu-Rukah, Y. and Shehadeh, H.M. Natural Radioactivity Concentrations in soil samples along the Amman Aqaba Highway,Jordan, Radiat.Meas. 36, 555560 (2003).

15. W.F. Wilson, A Guide to Naturally Occuring Radioactive Material (NORM), Penn Well Publishing Company, USA, 1994.

16. H.N. Singh, D., Shanker, V.N. and Neelakandan, V. P. Singh. Distribution of Natural Radioactivity and delineation of anomalous radioactive zones using in situ radiation observations in Southern Tamil Nadu, India. Journals of Hazadours materials. 141, 264-272 (2007).

17. Hanson, G.P. and Komarov, E. Health effects in residents of high background radiation regions. In: Biological Effects ofLow-Levels Radiation. Proceedings of an International Symposium on the Effects of Low-Level Radiation, Vienna, IAEA; IAEA-SM-266/81, 1983, 211-230 (1983).

18. http://en.wikipedia.org/wiki/Thiruvananthapuram_district.

19. A.P.Withanage and P.Mahawatte, Radioactivity of beach sand in South Western Coast of Srilanka, Radiation Protection Dosimetry Vol.153 (3), 384-389 (2013).

20. P.Otwama, I.P. Patel and A.O. Mustapha, Estimation of annual effective dose and radiation hazards due to natural radionuclides in Mount Homa, Southwestern Kanya, Radaiation Protection Dosimetry Vol.155 (4), 497-504 (2013).

21. N.M.Antovic, N.Svrkoto, I. Antovic, Radiological impacts of natural radioactivity from soil in motengro, Radiation Protection Dosimetry 1-8 (2011). 